\title{
PELATIHAN JARINGAN UNTUK MEMBANGUN JARINGAN WARNET, PERKANTORAN DAN INTERNET DESA (IbM)
}

\author{
Akim Manaor Hara Pardede, Novriyenni
}

STMIK KAPUTAMA,Binjai

Email: akimmhp@live.com

\begin{abstract}
Abstrak. Perkembangan teknologi informasi dan komunikasi semakin meningkat sesuai dengan perkembangan jaman dan kebutuhan masyarakat saat ini, sehingga hampir semua aktifitas atau pekerjaan sudah dikenai dan menerapkan teknologi informasi dan komunikasi. Perkembangan teknologi dan informasi membawa dampak ke dunia pendidikan, sehingga minat masyarakat untuk mengambil jurusan informatika komputer mencakup Teknik Komputer Jaringan, Audio Visual, Design Grafis, Teknik Informatika, dll terus meningkat baik tingkat sekolah menengah maupun tingkat perguruan tinggi. Banyaknya peminat jurusan komputer mengakibatkan kuatnya persaingan para lulusan untuk mendapatkan pekerjaan, sehingga perlu ada upaya penanggulangan untuk meningkatkan skill siswa-siswi dan lulusan jurusan komputer agar tidak semata-mata ingin mencari perkerjaan tetapi mampu membuka lapangan kerja. STMIK Kaputama terus melakukan kegiatan pengajaran, penelitian dan pengabdian masyarakat, melihat kuatnya persaingan lulusan dan kebutuhan masyarakat Kota Binjai dan sekitarnya, dosen STMIK Kaputama merasa terpanggil untuk melaksanakan pengabdian masyarakat untuk meningkatkan skill siswa SMK Tunas Pelita dan Abdi Negara dalam bentuk pelatihan perakitan komputer, instalasi sistem operasi dan pemasangan jaringan lokal dan internet untuk membangun jaringan warnet, perkantoran dan internet desa dalam meningkatkan kemandirian. Dengan adanya pelatihan perakitan komputer, instalasi sistem operasi dan pemasangan jaringan lokal dan internet, diharapkan siswa-siswi SMK Tunas Pelita dan SMK Abdi Negara dapat lebih meningkatkan skill dan jiwa wirausaha sehingga mereka mampu berwirausaha sekaligus membuka lapangan kerja secara khusus untuk dapat menerima perbaikan komputer dan membangun jaringan warnet, jaringan internet perkantoran dan jaringan internet masuk desa. Selain adanya jïwa wirausaha, masyarakat juga terbantu khususnya pedesaan agar percepatan informasi dan komunikasi dapat lebih meningkat.
\end{abstract}

Kata kunci: Jaringan Komputer, Internet, Jaringan Warnet, Jaringan Perkantoran, Jaringan Desa, SMK Wirausaha.

\section{PENDAHULUAN}

Kota Binjai sebagai salah satu kota di Propinsi Sumatera Utara yang hanya berjarak $\pm 22 \mathrm{Km}$ dari Kota Medan ( \pm 30 menit perjalan ), bahkan batas terluar Kota Binjai dengan batas terluar Kota Medan hanya berjarak $\pm 8 \mathrm{Km}$. Kota Binjai berbatasan langsung dengan Kabupaten Deli Serdang dan Kabupaten Langkat, serta berada pada Jalur Trasportasi Utama yang menghubungkan Propinsi Sumatera Utara dengan Propinsi Nangroe Aceh Darurralam (NAD) serta ke Objek Wisata Bukit Lawang Kabupaten Langkat. Secara geografis Kota Binjai terletak pada posisi $3^{\circ} 31^{\prime} 31^{\prime \prime}-3^{\circ} 40^{\prime} 2^{\prime \prime}$ LU dan $98^{\circ} 27^{\prime} 3^{\prime \prime}-98^{\circ} 32^{\prime}$ $32 "$ BT dan terletak $\pm 28 \mathrm{M}$ di atas permukaan laut.

Kota Binjai yang memiliki luas 9.023,62 Ha ( \pm 90,23 Km2) terdiri dari 5 (lima) Kecamatan dan 37 (tiga puluh tujuh) Kelurahan serta mempunyai penduduk sebanyak 252.652 jiwa yang terdiri dari berbagai Etnis antara lain Melayu,Batak Toba, Batak Mandailing, Batak Karo, Batal Simalungun , Jawa, Banten, Minang, Aceh, China dan India dengan pemeluk agama mayoritas Islam dan yang mempunyai kesadaran Politik dan Keamanan yang cukup tinggi, sehingga mendukung kondisi keamanan yang sangat konduktif. Kota Binjai sebagai Kota jasa, Perindustrian, Perdagangan dan Pemukiman telah berupaya memacu laju pertumbuhan Pembangunan yang mendukung Pertumbuhan Pembangunan yang mendukung Pertumbuhan Ekonomi Kota Binjai. Sementara itu Pendapat Asli Daerah (PAD) Kota Binjai pada tahun 2008 Rp.13.845.485.199. Sementara Pendapatan Domestik Regional Bruto (PDRB) berdasarkan Harga Berlaku tahun 2008 sebesar 15,04 persen. Hal ini menunjukkan kenaikan jika sebelumnya yaitu sebesar 14,58 persen pada tahun 2007. Laju pertumbuhan ekonomi Kota Binjai atas dasar harga konstan pada tahun 2008 sebesar 5,35 persen, Hal ini menunjukkan penurunan sedikit jika dibandingkan dengan tahun 2007 yaitu sebesar 5,68 persen (Sumber: http://www.binjaikota.go.id).

Program studi Teknik Komputer Jaringan di SMK Tunas Pelita dan SMK Abdi Negara dalam proses belajar mengajar mengikuti kurikulum sesuai dengan standard pemerintah, sehingga siswa-siswi memiliki kemampuan dasar untuk design dan instalasi jaringan. Mengingat saat ini pendidikan dalam bidang ilmu komputer yang sangat berkembang pesat baik dalam tingkat sekolah menengah maupun tingkat perguruan tinggi, menjadikan tantangan bagi lulusan SMK karena banyaknya kompetitor dan kuatnya persaingan baik dari tingkat SMK maupun dari tingkat lulusan perguruan tinggi. Secara umum siswa-siswi SMK memiliki pengetahuan umum tentang arsitektur jaringan, topologi, Ip addres, Mikrotik, pengkabelan, setting miktorik, wifi. Dalam hal konfigurasi mereka hanya mampu untuk setting maupun design untuk personal. Selain kemampuan dalam teknologi jaringan komputer, siswa-siswi juga memperoleh pengetahuan dalam bidang wirausaha yang di dapat dari bangku sekolah. 
Melihat kemampuan siswa-siswi dalam hal kemampuan dasar untuk membangun jaringan komputer serta pengetahuan dalam bidang wirausaha, sehingga siswa-siswi SMK Taman Siswa dan Swa Karya sangat potensial untuk dikembangkan sehingga mampu berwirausaha dalam hal membangun infrastruktur jaringan komputer dan internet, mampu membangun jaringan internet di warnet dan internet masuk desa. Mengingat sekarang ini perkembangan dunia infomasi dan komunikasi sangat pesat, tidak hanya diperkotaan tetapi juga sampai ke pedesaan. Wirausaha dalam hal penyediaan jasa pembangunan jaringan internet sangat menjanjikan.

Penerapan Ipteks melalui pengabdian masyarakat, kami sebagai dosen Tim dari STMIK Kaputama akan melatih siswa siswi SMK Tunas Pelita dan SMK Abdi Negara untuk membangun jaringan internet untuk warnet, kantor dan jaringan internet desa mencakup: Perakitan Komputer, Install Sistem Operasi pada client, Konfigurasi interface jaringan dan Mikrotik, Konfigurasi IP Addres, Konfigurasi Gateway, Konfigurasi DNS Server, Konfigurasi NAT, Konfigurasi DHCP, Subnetting, Membangun Server, MembangunProxy, Membangun Firewall, dan Management Bandwidth.

\section{METODE}

Untuk lebih jelasnya metode pelaksanaan pengabdian IbM yang diusulkan dapat di laksanakan dalam beberapa tahap (Faradisa, 2015), yang diGambarkan pada Gambar 1. Flowchar Pelaksanaan dibawah ini :

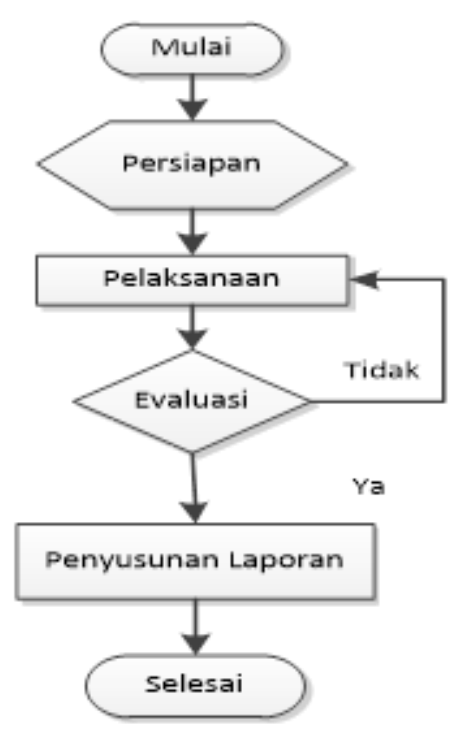

Gambar 1. Flowchart Pelaksanaan

Tahapan kegiatan pengabdian kepada masyarakat ini melalui beberapa tahapan, meliputi persiapan, pelaksanaan dan evaluasi.

\section{Persiapan}

Tahap persiapan dilakukan beberapa kegiatan, yaitu:

* Survei tempat pelaksanaan kegiatan, dalam hal ini adalah SMK Tunas Pelita dan dan SMK Abdi Negara.

- Wawancara dilakukan dengan Kepala Sekolah SMK Tunas Pelita yaitu Bapak EMRI Yulizal Ardi, S.Pd, dan Kepala Sekolah SMK Abdi Negara yaitu bapak Suparmin, S.Pd dengan tujuan untuk mengumpulkan data siswa dan terkait dengan keutuhan-kebutuhan pelatihan yang direncanakan

- Pembuatan modul, modul pelatihan dibagi menjadi tiga belas bagian sesuai dengan pelaksaan kegiatan

\section{Pelaksanaan Kegiatan}

Rencana pelaksanaan kegiatan dibagi menjadi beberapa tahap, yaitu:

* Pelatihan Perakitan Komputer, Install Sistem Operasi pada client, Konfigurasi interface jaringan dan Mikrotik, Konfigurasi IP Addres

* Pelatihan Konfigurasi Gateway, Konfigurasi DNS Server, Konfigurasi NAT, Konfigurasi DHCP, Subnetting

* Pelatihan Membangun Server, Membangun Proxy, Membangun Firewall, Management Bandwidth

* Pelatihan Kofigurasi dan instalasi jaringan Warnet

* Pelatihan Konfigurasi dan instalasi jaringan perkantoran 
* Pelatihan Konfigurasi dan instalasi jaringan internet desa

\section{Evaluasi}

Tahapan ini dilakukan untuk mengetahui tingkat keberhasilan kegiatan, sehingga dapat dilakukan penyempurnaan apabila ditemui kekurangan-kekurangan selama kegiatan pelatihan dilaksanakan. Evaluasi ini bertujuan untuk mengetahui apakah terdapat peningkatan

kemampuan siswa setelah dilakukannya pelatihan.

Evaluasi dilakukan dengan dua cara meliputi :

a. Pemberian Tugas :

$>$ Membuat sebuah rancangan pembangunan internet perkantoran, dengan menjelasakan Gambaran jaringan dan seting ip dan internet

> Membuat sebuah rancangan pembangunan internet desa, dengan menjelasakan Gambaran jaringan dan seting ip dan internet

b. Ujian Praktikum

$>$ Trouble shooting komputer

$>$ Perakitan komputer dan instalasi komputer

$>$ Instalasi jaringan dan internet

c. Kuisioner :

Dimaksudkan untuk mengetahui pendapat dari peserta pelatihan mengenai kegiatan ini, sehingga dapat diketahui apakah tujuan dari kegiatan ini sudah tercapai atau belum.

d. Penyusunan Laporan

Penyusunan Laporan terbagi menjadi dua laporan kemajuan dan laporan hasil.

\section{HASIL DAN PEMBAHASAN}

Pengabdian IbM Pelatihan Perakitan Komputer, Install Sistem Operasi Dan Pemasangan Jaringan Lokal Dan Internet Untuk Membangun Jaringan Warnet, Perkantoran Dan nternet Desa Dalam Meningkatkan Kemandirian Siswa SMK Tunas Pelita Dan SMK Abdi Negara Kota Binjai dilaksanakan sejak bulan Juni 2016 . Adapun kegiatan-kegiatan yang telah dilakukan

adalah sebagai berikut :

1. Sosialisasi akan diadakannya kegiatan pengabdian IbM pada Kepala Sekolah dan siswa SMK oleh tim pengabdian

2. Peninjauan lokasi tempat pendirian tiang pipa pemancar Akses Poin pada kedua mitra pengabdian pada SMK Tunas Pelita dan SMK Abdi Negara

3. Peninjauan tempat untuk kegiatan pelatihan dalam hal pengecekan ketersediaan alat- dan perangkat yang dibutuhkan selama kegiatan pelatihan kepada mitra pengabdian

4. Identifikasi alat-alat yang dibutuhkan oleh mitra pengabdian

5. Mempersiapkan kegiatan pelatihan kepada mitra pengabdian tentang materi pelatihan.

6. Melaksanakan kegiatan pelatihan pengabdian : Perakitan Komputer, Install Sistem Operasi pada client, Konfigurasi interface jaringan dan Mikrotik, Konfigurasi IP Addres, Konfigurasi Gateway, Konfigurasi DNS Server, Konfigurasi NAT, Konfigurasi DHCP, Subnetting, Membangun Server, Membangun Proxy, Membangun Firewall, Management Bandwidth.

7. Publikasi kegiatan pada Koran Metro Bijai-Langkat secara cetak dan online

\section{Rencana Tahapan Berikutnya}

Adapun rencana tahapan berikutnya yang akan dilakukan adalah:

1. Memantau perkembangan siswa-siswa SMK Tunas Pelita dan SMK Abdi Negara yang telah mendapatkan pelatihan.

2. Melalui grup IbM yang telah dibuat pada group facebook diharapkan menjadi ajang komunikasi antara siswa dan tim pelaksana pengabdian, sehingga pembimbingan dan pembimbingan dapat terus dilaksanakan.

3. Melakukan pendampingan setelah dilakukan pelatihan agar sesuai dengan harapan siswa-siswa dapat mendirikan usaha atau bisnis penjualan koneksi internet pada desa.

4. Melakukan publikasi proseding dan jurnal nasional terkait dengan kegiatan Pengabdian IbM Pelatihan Perakitan Komputer, Install Sistem Operasi Dan emasangan Jaringan Lokal Dan Internet Untuk Membangun Jaringan Warnet, Perkantoran Dan Internet Desa Dalam Meningkatkan Kemandirian Siswa Smk Tunas Pelita Dan Smk Abdi Negara Kota Binjai.

5. Melakukan testing penyerapan pengetahuan yang didapat oleh siswa-siswa SMK Tunas Pelita dan SMK Abdi Negara yang telah mendapatkan pelatihan, dan selanjutnya menerbitkan sertifikat pelatihan. 


\section{KESIMPULAN}

Dari kegiatan pengabdian pada masyarakat ini dapat disimpulkan bahwa:

1. Pengetahuan dan pemahaman siswa-siswi siswa - siswi SMK Tunas Pelita dan SMK Abdi Negara pada setiap sesi pelatihan menjadi meningkat.

2. Keinginan siswa-siswi SMK Tunas Pelita dan SMK Abdi Negara untuk berwirausaha meningkat, khususnya untuk membangun warnet milik sendiri dan menjual koneksi internet pada desa dengan memanfaatkan koneksi akses poin yang telah dipelajari pada saat pelatihan.

\section{DAFTAR PUSTAKA}

Faradisa,S.I. dan Santi,F.W. dan Wahyuni,Y. 2015, "IbM Pelatihan Dan Pendampingan Pembuatan Media Pembelajaran Interaktif Untuk Guru Sekolah Dasar Kelurahan Tasikmadu Dan Kelurahan Tunjungsekar Kotamadya Malang" , PROSIDING SEMINAR NASIONAL "RESEARCH MONTH" 2015 "Sinergi Hasil Penelitian dan Pengabdian kepada Masyarakat untuk Menumbuhkan Kapasitas Inovasi di Bidang Teknologi, Pertanian, Sosial dan Ekonomi”. ISBN:978-602-0856-43-8.

Fitriasih,S.H. dan Utami,Y.R.W. dan Kustanto, 2009 "Pelatihan Trouble Shooting Komputer untuk Karang Taruna Desa Banaran Kelurahan Banaran Kecamatan Grogol Kabupaten Sukoharjo", Jurnal Ilmiah SINUS, Vol.7, No.2, ISSN : 1693 - 1173.

Wulandari,B. dan Suparman dan Santoso,D dan Muslikhin dan Utami.A.D.W, 2015, "Pengembangan Trainer Equalizer Grafis Dan Parametris Sebagai Media Pembelajaran Mata Kuliah Praktik Sistem Audio", Jurnal Pendidikan Teknologi Kejuruan, e-ISSN 2477-2410,p-ISSN 0854-4735.

http://langkatkab.bps.go.id, diakses 25 April 2016

http://migas.bisbak.com/, diakses 25 April 2016 